\title{
DETEKSI DINI PENYAKIT DEGENERATIF PADA REMAJA ANGGOTA KARANG TARUNA
}

\author{
${ }^{(1)}$ Galuh Ratmana Hanum dan Syahrul Ardiansyah ${ }^{(2)}$ \\ ${ }^{(1,2)}$ Dosen Program Studi Analis Kesehatan, Fakultas Ilmu Kesehatan. Universitas Muhammadiyah Sidoarjo. \\ Email: (1) galuhratmanahanum@ymail.com, (2) syahrulardiansyah@umsida.ac.id
}

\begin{abstract}
ABSTRAK
Penyakit degeneratif adalah penyakit kronik yang mempengaruhi kualitas hidup seseorang. Diabetes mellitus dan hipertensi merupakan penyakit degeneratif. Penyakit degeneratif semakin berkembang karena menurunnya aktivitas fisik, gaya hidup dan pola makan. Tujuan kegiatan ini adalah untuk meningkatkan pengetahuan tentang gejala, komplikasi, pencegahan, dan terapi penyakit degeneratif khususnya penyakit diabtes mellitus dan hipertensi dan untuk mengetahui kadar glukosa darah dan tekanan darah kepada pada remaja anggota karang taruna Desa Ketegan Kecamatan Tanggulangin Sidoarjo. Kegiatan pengabdian pada masyarakat dapat dilaksanakan dengan baik dan berhasil hal ini ditinjau dari kelancaran acara dan partisipasi anggota karang taruna Desa Ketegan. Peningkatan kualitas kesehatan perlu dilakukan dengan membangun kesadaran dan peningkatan edukasi kepada anggota karang taruna serta perlu melakukan kontrol kesehatan secara teratur ke pusat kesehatan terdekat hal ini karena penyakit tersebut membutuhkan pengelolaan dan tata laksana yang termonitor secara berkala.
\end{abstract}

Kata kunci : Penyakit degeneratif, Hipertensi, Kadar glukosa.

\begin{abstract}
Degenerative disease is a chronic disease that influence the quality of life. Diabetes mellitus and hypertension are degenerative diseases. Degenerative disease progresses because decreased physical activity, lifestyle and dietary habit. The purpose of this activity is to improve the knowledge about symptoms, complications, prevention, and therapy of degenerative diseases, especially diabetes mellitus and hypertension and also to know the blood glucose and blood pressure level to the members of youth cadets of Ketegan village, Sub-disctrict of Tanggulangin, Sidoarjo. Community service activities can be carried out well and successfully. This is viewed from the smoothness of the event and the participation of members of youth cadets of Ketegan Village. The increase of the quality of health needs to be done by building awareness and increased education to members of youth cadets and need regular health control to the nearest health center because of this disease requires management and the eforcement system are monitored periodically.
\end{abstract}

Keywords: Degenerative disease, glucose level, hypertension.

\section{PENDAHULUAN}

Penyakit degeneratif adalah penyakit kronik yang mempengaruhi kualitas hidup seseorang. Diabetes mellitus dan hipertensi merupakan penyakit degeneratif. Penyakit degeneratif semakin berkembang karena menurunnya aktivitas fisik, gaya hidup dan pola makan. Penyakit degeneratif mempunyai tingkat mortilitas yang tinggi dan dapat mempengaruhi kuatitas hidup dan produktivitas seseorang.

Diperkirakan penderita diabetes mellitus akan meningkat dengan cepat dalam 25 tahun mendatang terutama pada negara berkembang karena menurunnya aktivitas fisik, gaya hidup dan pola makan. Kadar glukosa darah berhubungan dengan penyakit diabetes mellitus. Pemeriksaan kadar glukosa darah merupakan pemeriksaan tahap awal yang dilakukan bagi penderita diabtes mellitus .

Diabetes mellitus yaitu penyakit kronis yang disebabkan karena metabolisme tidak teratur. Kadar glukosa akan meningkat apabila sekresi insulin tidak mencukupi atau jika tubuh tidak bisa menggunakan insulin yang telah dihasilkan. Kadar glukosa darah dapat dipengaruhi dengan faktor endogen 
seperti hormon insulin, glukosa dan kortisol sedangan faktor eksogen seperti jenis dan jumlah makanan yang dikonsumsi dan aktivitas seseorang (Lestari, 2013).

Diabetes mellitus salah satu penyakit yang tidak dapat disembuhkan tetapi dapat dikendalikan dengan cara diet, olahraga dan mengkonsumsi buah-buah dan obat (Perkeni, 2011). Menururt World Health Organization (WHO), hipertensi atau tekanan darah tinggi merupakan kondisi yang terjadinya karena peningkatan tekanan pembuluh darah. Penderita hipertensi terjadi ketika tekanan sistolik lebih besar dari $140 \mathrm{mmHg}$ dan tekanan diastolik lebih besar dari $90 \mathrm{mmHg}$, tahap awal yang dilakukan bagi penderita hipertensi adalah pemeriksaan tekanan darah.

Penyebab hipertensi antara lain faktor keturunan, gaya hidup, pola makan, obesitas, konsumsi garam yang berlebih, merokok dan konsumsi alkohol. Menurut Sutanto (2009), gejala hipertensi seperti gejala ringan pusing, gelisah, tengkuk terasa pegal, mata berkunang-kunang dan mimisan. Tujuan kegiatan ini adalah yang pertama untuk meningkatkan pengetahuan remaja tentang gejala, komplikasi, pencegahan, dan terapi penyakit degeneratif khususnya penyakit diabtes mellitus dan hipertensi. Sedangkan tujuan yang kedua adalah untuk mengetahui kadar glukosa darah dan tekanan darah pada remaja anggota karang taruna Desa Ketegan Kecamatan Tanggulangin Sidoarjo.

Manfaat kegiatan ini diharapkan dapat meningkatkan pengetahuan tentang gejala, komplikasi, pencegahan, dan terapi penyakit degeneratif khususnya penyakit diabtes mellitus dan hipertensi. Disamping itu, kegiatan ini diharapkan dapat mengetahui kadar glukosa darah dan tekanan darah pada remaja anggota karang taruna Desa Ketegan Kecamatan Tanggulangin Sidoarjo supaya dapat mengontrol kesehatan dengan baik.

\section{METODE PELAKSANAAN}

Kegiatan ini dimulai setelah melakukan observasi dan pendataan. Hasil pendataan tersebut dipergunakan sebagai bahan dan acuan untuk mengidentifikasi masalah yang dapat dirumuskan menjadi sebuah program kerja. Jenis kegiatan yang dilaksanakan dalam kegiatan ini yaitu pemeriksaan kadar glukosa darah dan tekanan darah. Metode pelaksanaan pada kegiatan pemeriksaan kesehatan adalah dengan cara pengambian darah perifer untuk mengetahui kadar glukosa darah dan pemeriksaan tekanan darah dengan menggunakan tensimeter.

Kegiatan selanjutnya adalah penyuluhan kesehatan dan konsultasi tentang penyakit degeneratif. Populasi pada kegiatan ini adalah anggota karang taruna Desa Ketegan Kecamatan Tanggulangin Sidoarjo yang berumur 15-25 tahun. Kegiatan pengabdian pada masyarakat seperti pengumpulan data, pengukuran kadar glukosa darah dan tekanan darah, penyuluhan kesehatan dan konsultasi dilakukan oleh pelaksana kesehatan yang berkompeten.

\section{HASIL DAN PEMBAHASAN}

Kegiatan pengabdian pada masyarakat dengan tujuan pemeriksaan kadar glukosa dan tekanan darah serta penyuluhan tentang penyakit degeneratif berjalan dengan lancar dan disambut secara antusias oleh karang taruna Desa Ketegan Kecamatan Tanggulangin Sidoarjo. Hasil kegiatan pengabdian pada masyarakat ini didapatkan data status kesehatan berupa kadar glukosa dan tekanan darah pada 31 anggota karang taruna Desa Ketegan Kecamatan Tanggulangin Sidoarjo yang berumur 15-25 tahun.

Hasil yang didapat pada kegiatan ini adalah data kadar glukosa dan tekanan darah 20 anggota karang taruna normal, 6 anggota karang taruna memiliki tekanan darah di atas normal $(120 / 80 \mathrm{mmHg})$ sedangkan 5 anggota karang taruna memiliki kadar glukosa diatas normal $(140 \mathrm{mg} / \mathrm{dl})$. Tekana darah yang tinggi atau hipertensi disebabkan oleh beberapa faktor risiko antara lain umur, obesitas, merokok, konsumsi alkohol dan diabetes. Sedangkan kadar glukosa yang tinggi dapat disebabkan oleh beberapa faktor risiko antara lain umur, hormon insulin, stres, pola makan dan aktivitas yang dilakukan (Lestai, 2013)

Berdasarkan hasil pengamatan dilapangan, didapatkan kurangnya kesadaran 
untuk memeriksakan diri secara rutin ke Puskesmas terhadap masalah kesehatan dan pengetahuan tentang penyakit degeneratif yang kurang hal ini tercermin dari pertanyaan yang diajukan. Setelah kegiatan dilakukan, anggota karang taruna memahami bahwa pemeriksaan kesehatan sangat bermanfaat dan penting dilakukan baik dalam keadaan sehat atau sakit untuk mengetahui kesehatan diri, sehingga tidak terlambat untuk mencegah dan mengambil tindakan.

Selain itu, anggota karang taruna juga lebih mengenal dan memahami tentang penyakit degeneratif seperti tekanan darah tinggi atau hipertensi dan kadar gula yang tinggi, termasuk penyebabnya, ciri-ciri dari tekanan darah tinggi atau hipertensi dan kadar gula yang tinggi, bagaimana cara mencegah dan mengobatinya, serta apa saja komplikasinya sehingga penyakit tersebut akan lebih cepat ditangani sebelum menimbulkan banyak komplikasi. Oleh karena itu, kegiatan semacam ini sangat diperlukan bagi anggota karang taruna dengan materi yang menyesuaikan dengan permasalahan yang dialami di daerah tersebut.

\section{KESIMPULAN}

Kegiatan pengabdian pada masyarakat dapat dilaksanakan dengan baik dan berhasil hal ini ditinjau dari kelancaran acara dan partisipasi anggota karang taruna Desa Ketegan. Peningkatan kualitas kesehatan perlu dilakukan dengan membangun kesadaran dan peningkatan edukasi kepada anggota karang taruna serta perlu melakukan kontrol kesehatan secara teratur ke pusat kesehatan terdekat hal ini karena penyakit tersebut membutuhkan pengelolaan dan tata laksana yang termonitor secara berkala. Dengan demikian; (1) diharapkan penderita hipertensi dan diabetes Mellitus supaya menurunkan berat badan dengan cara meningkatkan aktivitas, mengurangi stres, dan memperhatikan asupan makanan seharihari, (2) Penyuluhan sebaiknya berisi informasi tentang gizi seimbang, pola hidup dan pola makan yang baik serta risiko penyakit yang muncul jika seseorang menderita penyakit degeneratif.

\section{REFERENSI}

Darmojo \& Martono. 2006. Buku Ajar Geriatri (Ilmu Kesehatan Usia Lanjut). Jakarta: Balai Penerbit FKUI.

Dewi, E.U. (2015). Gambaran Faktor-Faktor yang Memengaruhi Terkendalinya Kadar Gula Darah padaPasien Diabetes Mellitus di Puskesmas Pakis Surabaya. Jurnal STIKes William Booth.

Direktorat Bina Farmasi Komunitas dan Klinik Ditjen Bina Kefarmasian dan Alat Kesehatan Depkes. 2006. Pharmaceutical Care Untuk Penyakit Hipertensi.

Hajjar I, Kotchen TA. 2003.Trends In Prevalence, Awareness, Treatment, And Control Of Hypertension In The United States, 1998 - 2000. JAMA .290:199-206.

$\mathrm{He} \mathbf{J}$ et al. 2000. Long-Term Effects Of Weight Loss And Dietary Sodium Reduction On Incidence Of Hypertension. Hypertension 35:544549 Suryanto., 2011. Peranan Pola Hidup Sehat terhadap Kebugaran Jasmani. Universitas Negri Yogyakarta.

Ndraha, S. (2014). Diabetes Melitus Tipe 2 dan Tatalaksana Terkini. Departemen Penyakit Dalam Fakultas Kedokteran Universitas Krida Wacana Jakarta.

Notoatmodjo, Soekidjo. 2003. Ilmu Kesehatan Masyarakat (Prinsip Prinsip Dasar). Jakarta : Rineka Cipta. Pusat Promosi Kesehatan, Depkes RI.

Soekidjo, Notoatmodjo.(2007).Kesehatan masyarakat,edisi ke 11.Jakarta : Rineka Cipta.

Syamiyah, N. (2014). Faktor Risiko Kejadian Diabetes Mellitus Tipe 2 pada Wanita di Puskesmas Kecamatan Pesanggrahan Jakarta Selatan Tahun 2014. Skripsi. Universitas Islam Nasional Syarif Hidayatullah, Jakarta. 